
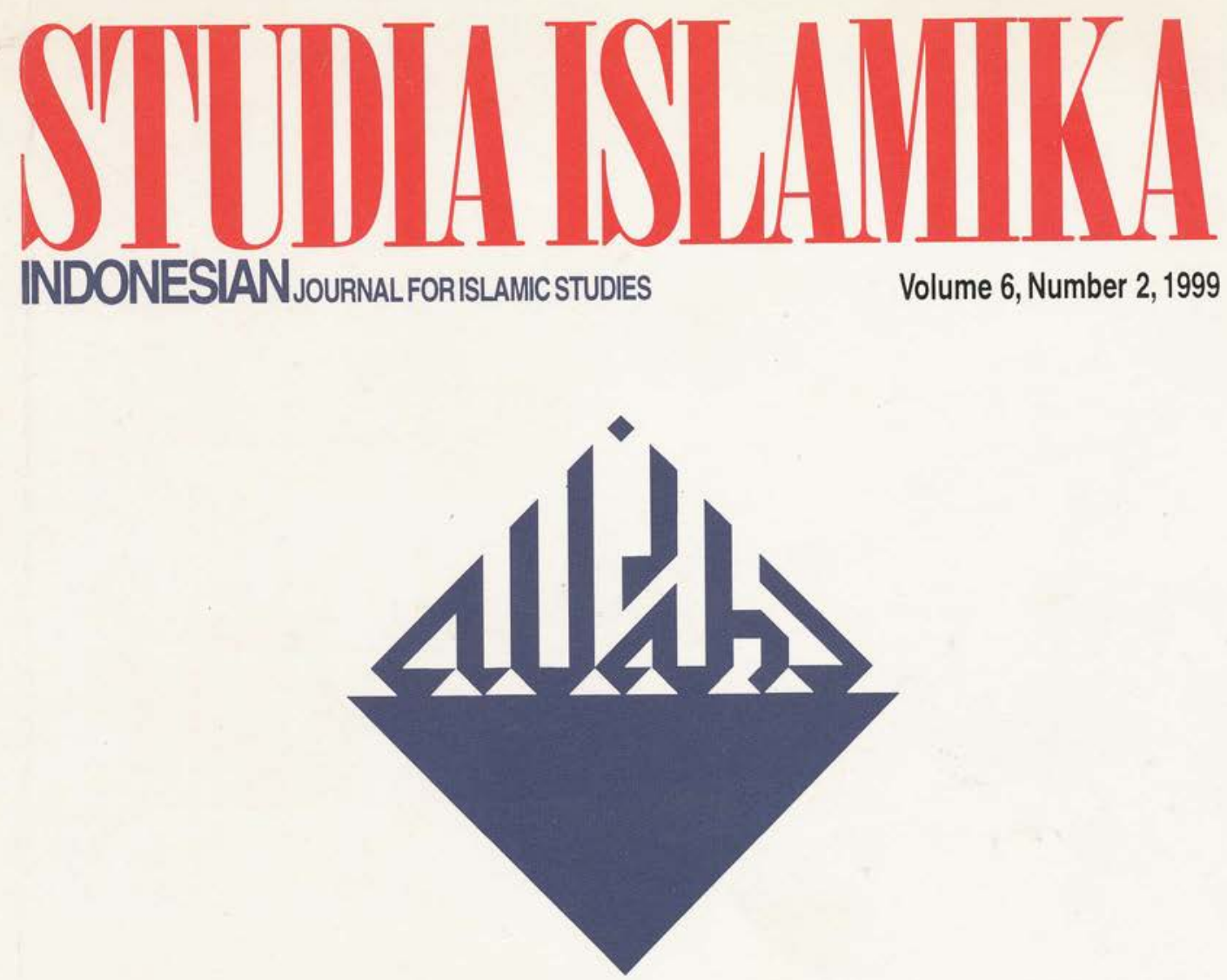

AT THE SOURCES OF INDONESIAN POLITICAL ISLAM'SFAILURE:

THESPLIT BETWEEN THENAHDLATUL ULAMAAND

THE MASYUMI IN RETROSPECT

Rémy Madinier and Andrée Feillard

RECENT TRENDS INISLAMIC REVIVALISM

IN MALAYSIA

Muhammad Syukri Salleh

LAW AND POLITICS IN POST INDEPENDENCE INDONESIA:

A CASE Study OF RELIGIOUSAND ADATCOURTS

Ratno Lukito

TABUT: MUHARRAMOBSERVANCES

IN THE HISTORY OFBENGKULU

R. Michael Feener 


\section{SIIIDIISLAIIIKA \\ Indonesian Joumal for Islamic Studies \\ Vol. VI, no. 2, 1999}

\section{EDITORIAL BOARD:}

Harun Nasution

Mastuhu

M. Quraish Shiliab

A. Aziz Daltan

M. Satria Effendi

Nabilah Lubis

M. Yunan Yusuf

Komaruddin Hidayat

M. Din Syamsuddin

Muslim Nasution

Wahib Mu'thi

EDITOR-IN-CHIEF:

Azyumardi Azra

EDITORS:

Saiful Mujani

Hendro Prasetyo

Johan H. Meuleman

Didin Syafruddin

Ali Munhanif

Assistants to THE EDITOR:

Arief Sublian

Oman Fathurrahman

Heni Nuroni

English Language Advisor:

Richard G. Kraince

Arabic Language Advisor:

Nursamad

Cover Designer:

S. Prinka

STUDIA ISLAMIKA (ISSN 0215-0492) is a journal published quarterly by the Institut Aganta Islam Negeri (IAIN, the State Institute for Islamic Studies) Syarif Hidayatullah, Jakarta. (STT DEPPEN No. 129/SK/DITJEN/PPG/STT/1976) and sponsored by the Department of Religious Affairs of the Republic of Indonesia. It specializes in Indonesian Islamic studies, and is intended to communicate original researches and current issues on the subject. This journal warmly welcomes contributions from scholars of related disciplines.

All articles published do not necessarily represent the views of the journal, or other institutions to which it is affiliated. They are solely the views of the authors. The articles contained in this journal have been refereed by the Board of Editors. 


\title{
At the Sources of Indonesian Political Islam's Failure: The Split between the Nahdlatul Ulama and the Masyumi in Retrospect
}

\begin{abstract}
Abstrak: Artikel ini merupakan kajian dua orang sarjana, yang masing-masing mendalami perkembangan reformisme Islam di Indonesia, khususnya Masyumi, dan traditionalisme Islam, kbususnya Nabdlatul Ulama. Artikel ini membahas konteks politik gagalnya kerja sama kedua aliran Islam di atas, dengan bertolak dari pecabnya Masyumi pada 1952. Pada tabun itu, NU keluar dari Masyumi dan kemudian menjadi partai politik sendiri. Pada bagian kedua artikel ini, pembahasan artikel ini selanjutnya diarabkan untuk menganalisis perkembangan lebib lanjut konflik dan persaingan tersebut selama periode 1970-an bingga sekarang ini.
\end{abstract}

Sejalan dengan pandangan umum yang berlaku, penulis artikel ini berpendapat babwa salab satu faktor utama keluarnya NU dari Masyumi pada 1952 adalab ditolaknya tuntutan NU untuk jabatan menteri agama. Namun, mereka menambabkan babwa keputusan NU tersebut tidak bisa dilihat senmata-mata bersifat oportunis, melainkan merupakan tindakan bela diri:penguasaan Departemen Agama menentukan masa depan kedua aliran Islam yang sudab bersaingan sejak awal abad ini. Salah satu pokok perselisiban utama adalab kedudukan dan fungsi para ulama dalam masyarakat, negara, dan partai Masyumi. Pada masa penjajahan, para ulama menduduki posisi relatif terhormat. Namun, pada masa kemerdekaan, kaum reformis semakin mempersoalkan kedudukan itu. Kongres Masyumi pada 1949 telah menggeser para ulama dari jabatan utarna dalam partai, dan menyerabkannya kepada sejumlab tokob berpendidikan modern yang kurang menghargai dan menghormati para ulama.

Pembahasan artikel ini berlanjut dengan membandingkan program Masyumi dan NU pada Pemilihan Umum 1955. Program NU merujuk pada tradisi fikih Islam dan mengusulkan suatu majelis ulama sebagai permecaban utama atas berbagai persoalan prinsip dalam negara. Pro- 
gram Masyumi kurang merinci urusan bukum. Penulis menyimpulkan babwa perbedaan program antara kedua partai terlalu kecil untuk menjelaskan perpecahan yang berkelanjutan, dan seraya menegaskan babwa perselisiban pandangan tentang kedudukan ulama lebih menentukan. Pada tingkat pedesaan, penulis menambabkan, konflik tajam antara kelompok reformis dan tradisionalis bertaban lebih lama daripada pada tingkat politik nasional.

Perrpecahan antara kedua aliran itu berlanjut selama periode Dernokrasi Terpimpin dan Orde Baru. NU ikut serta dalam pemerintaban Demokrasi Terpimpin, sedangkan Masyumi, yang akbirnya dipaksa bubar, mengambil posisi berlawanan. Sikap saling curiga antara kaum reformis dan NU bertaban sampai pada masa Orde Baru, di mana NU menghindari upaya pemuliban suatu aliansi politik, yang diduga akan kembali menjadikannya sebagai kubu yang didominasi. NU menerima menjadi bagian dari Partai Persatuan Pembangunan (PPP), sedangkan generasi lama eks-Masyumi memusatkan perhatian pada bidang dakwah melalui Dewan Dakwah Islamiyah Indonesia (DDII).

Pada 1980-an, penulis melanjutkan, organisasi utama kaum reformis dan tradisionalis, Muhammadiyab dan NU, saling mendekati lagi. NU keluar dari PPP dan ikut memusatkan perhatiannya pada bidang budaya dan sosial. Tabun 1990-an membawa perubaban lagi. Dengan berdirinya ICMI, sebagai usaha mencari dukungan baru pada saat angkatan bersenjata mulai kurang dapat diandalkan, Presiden Soeharto memberi ruang baru pada Islam politik. Menarik sekali, seperti digarisbawabi penulis, $N U$ pada periode ini bersifat lebih terbuka terhadap kelompok non-Muslim, seperti Masyumi dabulu. Sementara ICMI, yang dikuasai kaum reformis, mengajukan tuntutan akan jatab jabatan menteri bagi kaum Muslim, seperti NU dabulu. Penulis melanjutkan analisis kesinambungan dan perubahan itu dengan mengangkat persoalan sejaub mana sikap tokoh reformis utama dewasa ini, Amien Rais, dan tokob tradisionalis utama, Abdurrahman Wahid, mencerminkan tradisi kelompok masing-masing atau justru bertolak belakang dengannya.

Penulis menutup dengan pernyataan babwa kejadian pada Mei 1998, serta sikap Amien Rais dan Abdurrabman Wabid pada saat itu, tidak dapat dipahami terlepas dari hubungan segi tiga antara pemerintah, kaum reformis, dan kaum tradisionalis sebagaimana digambarkan dalam analisis historis dan politis ini. Di lain pibak, mereka memperingatkan, perundingan antara partai seusai pemiliban umum 1999 serta menjelang pemilihan presiden mendatang tampaknya lebih ditentukan strategi pribadi berbagai tokoh daripada persoalan program politik. 


\section{At the Sources of Indonesian Political Islam's Failure: The Split between the Nahdlatul Ulama and the Masyumi in Retrospect}

خلاصة: تأتى هذه المقالة نتيجة لدراسة قام بها باحثان، كل منهما قد تـابع عن كثب الآتحاه الاصلاحي باندونيسيا وماشومى (Masyumi) بصفة خاصة والاتجّاه

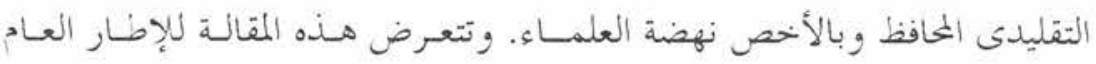

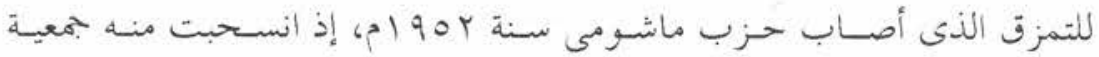

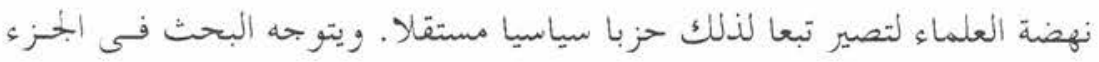

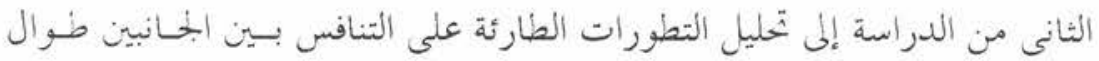
فتزة السبعينيات حتى الآن.

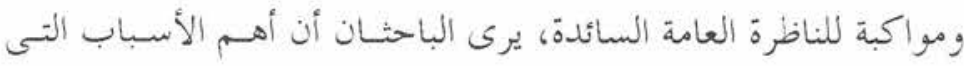

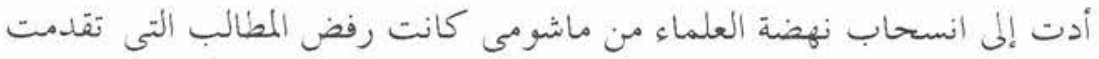

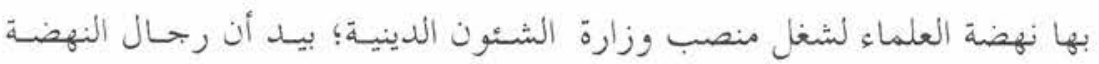

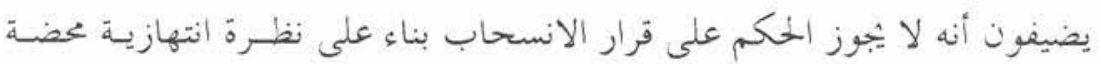

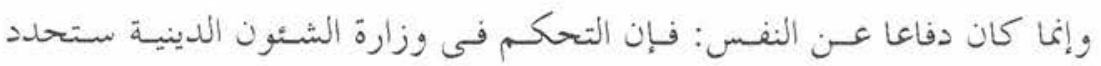

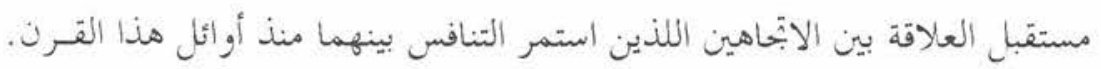

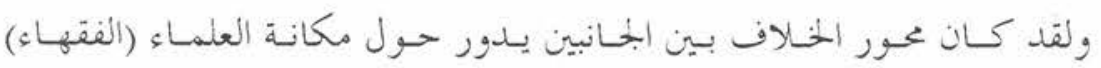

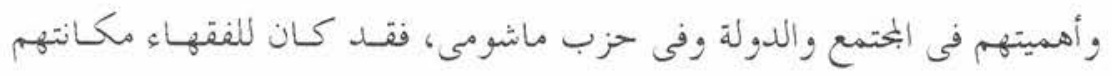


المرموقة نسبيا فى عهد الاستعمار، بيد أنه في عهد الاستقلال ازداد الاصلاحيون معارضة لتلك المكانة؛ وكان مؤتمر ماشومى المنعقد سنة و 9 ام قد أبعد العلماء عن شغل المناصب الهامة في الحزب وتم تبديلهـم بعـدد مسن الشـخصيات الذيـن كانوا يتمتعون بالتزبية الحديثة و مـ يكنوا احتراما للعلماء. ويمضى البحث إلى عقد مقارنة بين البرامج الحزبية التى يخططها كلى من ماشومى وجمعية نهضة العلماء للدخول فـى الانتخابـات العامـة لسـنة 900 امه، فقد وضع حزب نهضة العلماء خططها بناء على الفقه الاسلامي لمعالجــة بختلف المشاكال المبدئية للدولة. و أما حزب ماشومى فلم يتعرض للفقه بشكال تفصيلي. وقد توصل الباحثان إلى أن هـذه الـبرامج كـانت أدنى أن تكـون مرجعـ لبيـان اخخلاف المستمر بين الجانبين، مؤكدين أن للخلاف حول مكانة العلمـاء أهميتـه القصوى. ويضيفان أنه فى مستوى القرى والأرياف كـان الصـراع على أشـده بين الإصلاحيين والتقليديين المحافظين ويستمر فترة أطول مما فى المستوى القومي.

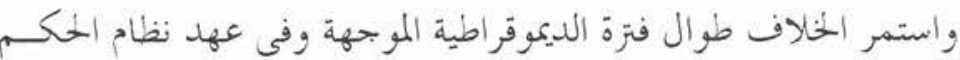
الجديد، حيث شاركت نهضة العلماء فى تكوين حكومة الديموقراطيـة الموجهـة، بينما اضطر حزب ماشومى فى النهاية إلى اتخاذ طريق المعارضة. وبقي التشكك

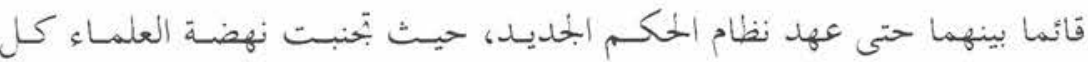
محاولة لإعادة توحيــ الاتجاهـات السياسية التى تعتبرهـا نضهة العلمـاء وسـيلة للهيمنة عليها هي. ورحبت نهضة العلماء لنفسـها أن تكون جـزءا في تكويسن حزب الاتحاد التنموي (PPP) (Partai Persatuan Pembangunan (Pينما توجـهـ اهتمام رجال ماشومى الأسـبق إلى الـركيز على شـئون الدعـوة الاسـلامية مسن خـالال بحلسـ الدعـوة الاسـلامية الاندونيسـية Dewan Dakwah Islam) .Indonesia (DDII) ويمضى الباحثان فى عرضهما فأشارا إلى أنه فى فترة الثمانينـات حـدث

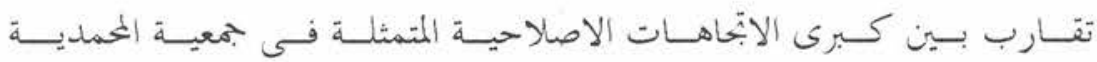


والاتبحاهـات التقليديـة المحافظـة المتمثلـة في جمعيـة نهضــة (Muhammadiyah) العلماء. فقد انسحبت نهضة العلماء من حزب الاتحاد التنموي لتصب اهتمامهـ هي الأخرى على الشئون الثقافية والاجتماعية. وفى فتزة التسعينات حدث تطور

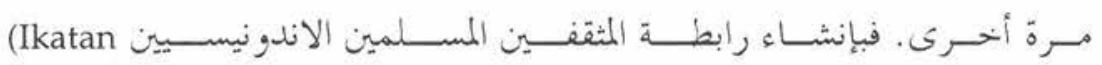
Cendekiawan Muslim se-Indonesia (ICMI)) جديد فى الوقت الذى تناقص فيه تأييد الجيش، أفسـح الرئيس سـوهارتو البحـال للإسلام السياسي. ومن العجب، كما لاحظ الباحثان، أن موقف نهضة العلمـاء في هذه الفترة كان أكثر تفتحا لغـير المسـلمين، وهـو الموقف الـذى اصطبـ بـهـ حزب ماشومى سابقا؛ بينما الثّهت رابطة المثقفـين المسـلمين وقـد سيطر عليها اصحاب الاتجاه الاصلاحي، إلى المطالبة بإعداد المناصب الوزاريسة، وهـو الموقـف

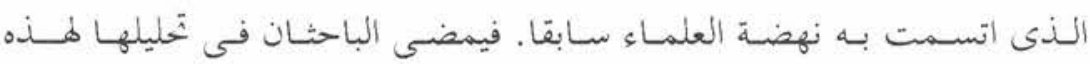
الاستمرارية والتغيرات فقدما سؤالا مفاده إلى أي مدى كان موقف كل من أهم رجال الاصلاحيين الآن وهو أمين رئيس (Amien Rais) وأهم رجال التقليديسين

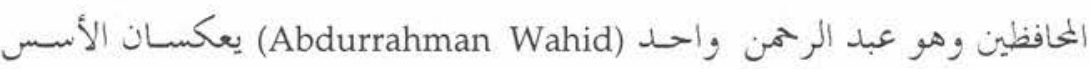
المذهبية التى يمثلانها؟ أم أن موقفهما يتعارض مع تلك الأسس.

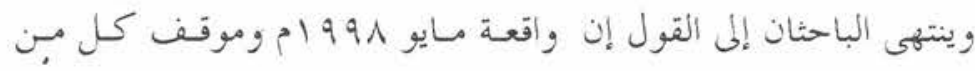

أمين رئيس وعبد الرحمن واحد حيالها، لا يمكن فهما بعيـدا عـن العلاقـة الثلاثيـة

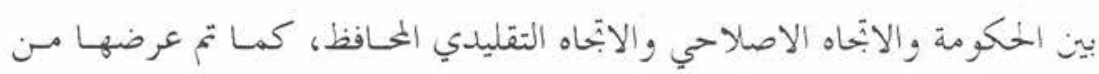
خلال هذه التحليلات التاريخيـة والسياسية. وينبهـان مسن ناحيـة أخـرى إلى أن نتائج المشاورات بين الأحزاب عقب الانتخابات العامة لسـة و99 99 إب والإقبـال على اختيار رئيس الدولة ستتحدد فيما يبدو بناء على استراتيجيات فرديـة أكثر منزا أن تكون بر امعج سياسية. 
I $\mathrm{n}$ the eyes of a population accustomed to frequent cabinet crises, the formation of the Wilopo cabinet on A pril 1s, 1952 may have looked like just another episode on the lively political scene of a young independent republic. Seeing that the two largest political parties, the nationalist PNI (Partai Nasional Indonesia) and the Muslim Masyumi, were both part of the new cabinet, the public could even nurse the hope that this, the fourteenth cabinet since independence, could at last start to organize the first general elections that could put an end to a seven-year period of political instability.

The Wilopo cabinet became a "turning point" in Indonesian political history, as it was the source of a definitive split between Muslim traditionalists and their opponents, the modernists. Islam's political representation segmented irreversibly, and not even the forced merger of four Islamic political parties into the Partai Persatuan Pembangunan $(\mathrm{PPP})^{+}$in 1973 could mend the split.

Because Masyumi united modernists and traditionalists for a time (between 1945 and 1952), the party became a symbol of the ummat's (the Muslim community's) political potential. In analyzing the reasons for its political failure as the sole embodiment of the ummat, we can in part explain the "minority mentality" mentioned by Wertheim in his description of Muslims under the New Order.

In this article, we intentionally emphasize the analysis of the political context, while touching only slightly on sociological considerations. We proceed from the fact that the sociological differences could be overcome, since the two currents once succeeded in uniting into Masyumi. Moreover, we wanted to look beyond common notions of basic disagreements, such as the oft-noted conflict where reformists frequently despise traditionalists' penchant for Sufism, for the supernatural, and for the irrational, which they consider to be everywhere the "cause" of general backwardness of Muslim countries in terms of technology (kemunduran), while the latter tend to criticize reformists for their puritan behavior and for their great hostility to local tradition. Traditionalists also commonly blame reformists for their "dryness" (kekeringan), while the latter feel proud of being closer to a "pure" Middle-Eastern model. We have also tried to put aside considerations of class differences, traditionalists being generally closer to lower rural classes, modernists being more numerous in urban middle-classes. Our purpose was to deal with the political context and the discourse on both sides to try and determine why political union failed despite the repeatedly heralded desire of unity. 
The first part focuses on the 1952 historical split as the source and clearest manifestation of old rivalries and disagreements. The last part deals with the period from the 1970s to the 1990s, but we did not pretend to be exhaustive on these more recent years, marked by their failure to reunite, as our purpose here was only to provide some clues to the reader to better understand current political rivalries.

\section{The Circumstances Leading to the 1952 Split}

Shortly after the disclosure of the cabinet configuration, on April 1, 1952, the Nahdlatul Ulama (NU) leadership announced its intention to withdraw from Masyumi. ${ }^{6}$ A few weeks later, on April 26, NU's congress opened in Palembang and confirmed this decision by a large majority of votes (61 in favor and 11 against). The Nahdlatul Ulama was emerging as an independent party, proposing to Maysumi an alliance within a new federation.

The Masyumi leadership did not seem to properly assess the importance of the event, and NU's decision to stand apart was addressed with disdain and skepticism. In the eyes of the Muslim party's leaders, NU was merely trapped in an impasse to which it had been pushed by its own maneuvers over the past months. Indeed, during the delicate negotiations that led to the new cabinet configuration, NU had set its conditions. As early as March 15th, K.H. Abdul Wahab, NU's rais aam, ${ }^{8}$ had told the man forming the cabinet, Wilopo (from the PNI), that he wanted to see Sukiman, ${ }^{9}$ who had headed the former cabinet, renamed as head of the government. He also wanted Abu Hanifah at the foreign ministry, Zainul Arifin at defense, and Wahid Hasyim at the ministry of religions. ${ }^{10}$ This last request turned into a firm demand on March $20^{\text {th }}$. It soon became apparent that if the ministry of religions was to escape NU, then the traditionalists would leave Masyumi altogether. Hamka, a Muhammadiyah leader, vigorously protested NU's position which he said was contrary to that usually taken by the party. Hamka noted that cabinet decisions were the central leadership's jurisdiction, not the extraordinary members'. The Muhammadiyah had its own candidate for the Ministry of Religions, a post it had held only once previously. ${ }^{11}$ This candidate, Faqih Usman, had also been the choice of the Masyumi leadership that had had to decide among eight candidates for the post. In the end Faqih became the new Minister of Religions.

Although relatively insignificant in the cabinet hierarchy (ranking only 16th), the Ministry of Religions was an essential posting for the major Muslim organizations. The ministry was indeed a place from where 
influence could be exercised on general government policies, but it also represented a huge source of patronage for posting in the administration (teachers, mosque officials, religious judges), which permitted the minister to become a patron of part of his constituency. Moreover, and just as importantly-and this factor has often been neglected in previous analysis-the holding of the ministry was essential to promote either NU's or Muhammadiyah's dogma, traditionalist or reformist, across the wide archipelago.

But, whatever the stakes, in the words of the reformists in Masyumi, the NU had not respected the rules of the procedure in directly addressing Wilopo. It had, moreover, through its decision to create its own political party, "broken the ummat's unity".

As early as April $16^{\text {th }}$, an editorial in Hikmah, a weekly directed by Moh. Natsir, commented that the affair was mere politicking and refused any other explanation for NU's departure:

According to the Nahdlatul Ulama, this question [of whom the ministry of religions should go to] is "incidental", ${ }^{12}$ but, if one takes a closer look, it becomes evident that this incidental factor is the principal one.

Further implying NU's total responsibility, the editorial declared: ${ }^{13}$

All those who have taken time to carefully study the problem will be convinced that the ummut is not actually disunited, but that it is its leaders who have brought the division into it.

As for the decision to transform the Nahdlatul Ulama into a political party, modernist leaders received it with disdain. As a 1954 brief summary of the events by the traditionalists recalls, the modernists had not even taken the trouble to answer the remarks and proposals made by the NU at the time of the threat of the split: ${ }^{1+}$

Thus, at its Palembang congress, the Nahdlatul Ulama decided to separate from Masyumi and invited Masyumi to transform itself into a federation where parties and Islamic organizations would become members, in order to consolidate the struggle of the ummat. But alas, the NU congress proposal was not even discussed.

Masyumi vice-president Prawoto Mangkusasmito made a public statement in one of the rare public reactions of the Masyumi leadership. In a press interview, he described the gloomy fate awaiting the Nahdlatul Ulama outside the Masyumi:

If we accept the common understanding that Masyumi is a rightist party, then, given the objective information that is now available, the NU will be a party of the extreme-right. And there is a truth that is confirmed by history, namely that it is in the nature of extremist parties, be they on the left or on the right, to always be in the opposition. And, let us suppose they take the reins of power, then, progressively, the government will take a dictatorial turn. 
These comments, reported in the May 10, 1952 edition of Hikmah, display the great bitterness of modernist leaders, but also their deep distrust of the ulama's capacity of autonomy once they dared to move outside their traditional religious field. They were accused both of religious extremism and of political opportunism, an awkward combination indeed.

This last accusation was based on Soekarno's intervention in the debate. The Indonesian president was unhappy to see the influence of Sukiman, with whom he was on friendly terms, decline in favor of Moh. Natsir, with whom relations had been most contentious during Natsir's tenure as Prime Minister between 1950 and 1951. It is known that Soekarno had a long talk with Kyai Wahab Hasbullah shortly before the split announcement, and that Wahab shared the same dislike of the new Masyumi leadership. Whereas the content of their talks still remains unknown, one can suppose that the president might have been rather encouraging to the creation of a new independent traditionalist political party, nearer to his own political line than would be a Masyumi headed by Moh. Natsir.

Thus, the prevailing view that the NU declined to stay in Masyumi because it lost - with the ministry of religions-its source of patronage is exact, although it is, in our view, only part of a complex setting. First of all, the apparent hostility, and at times disdain, of some of the modernists for what they saw as an "extreme-right" current, seems to have amplified the breach. Secondly, NU's rupture can hardly be reduced to accusations of "opportunism": it was rather an act of self-defense upon which survival was dependent. Indeed, the Ministry of Religions was not merely a source of patronage, but also the key institution that gives guidelines for religious education, and, as such, it determines the longterm future of the two variants of Islam, reformist and traditionalist, in their protracted competition. We will elaborate on these stakes in another part of this article.

\section{The Myth of Unity: From the 1920 s to Independence}

Listening to the castigations of Masyumi leaders, it may sound as if the Nahdlatul Ulama had taken the unfortunate initiative in 1952 to break a solid tradition of unity within the Muslim community. A closer look at the history of Islamic movements since they emerged in the 1910s rather shows a tendency toward disunity than the reverse.

As for the Dutch colonial period, let us recall here that the 
Nahdlatul Ulama was created essentially as a consequence of the refusal of modernist leaders to take over a minimum of the demands of traditionalists at a time of deep preoccupation, when wahhabism was triumphing in the Hejaz. ${ }^{15}$

Let us also recall the strong divisions within the Partai Sarekat Islam Indonesia (PSII), its rupture with the Muhammadiyah in 1927, and the creation, in the thirties, of several dissident parties: Partai Islam Indonesia (PARTII) in 1933, Barisan Penyadar (Consciousnessraising Front) PSII in 1936, Komite Pertahanan Kebenaran (Comittee for the Upholding the Truth) PSII in 1938, and PII (Partai Islam Indonesia) in 1938.

Masyumi, as the inheritor of the old MIAI, ${ }^{16}$ the first real attempt at uniting diverging Islamic currents, benefited from a powerful élan which attracted all Islamic organizations to join it at its creation in November 1945. But, already in December of the same year, the Perti, a small Sumatran party, withdrew, disappointed to see the key posts end up in modernist hands. Worse for the ummat's unity, in 1947, part of the old PSII leaders, also disappointed at the fate they were given within the Masyumi leadership, announced their departure and tried to revive the old party of Tjokroaminoto. Without much consequence on the electoral map - Perti and PSII obtained a mere 1.3 percent and 2.9 percent respectively in the 1955 general elections these first rifts in the Islamic representation could only have encouraged the Nahdlatul Ulama to strive for more autonomy: ${ }^{7}$

The PSII leaders reactivated their party, so that Masyumi's position was no longer one of a united front within the Muslim community, and the Nahdlatul Ulama saw that the Masyumi could no longer pretend to remain the only Islamic political party. The NU then deemed it necessary to introduce changes and to transform the Masyumi into a federation.

This tendency toward division did not affect Islamic parties only. With no less than twenty-three organizations represented in Parliament, the Indonesian political scene appeared very fragmented and was in fact an ideal breeding ground for small organizations with a desire for autonomy. Thus, parliamentary commissions were set up on the basis of one member for one party, without consideration of the size of the party. In August 1950, the same method was used for nominations at the provincial parliamentary committees in regencies (kabupaten) and districts in Java and Sumatra. ${ }^{18}$ The myth of ummat unity thus does not survive a closer look at the 1920s and the 1930s. 
Finally, the hypothesis of the role of Soekarno in the split obscures a key divisive issue between the two Islamic movements. Indeed, the antipathy of the modernists towards the ulama, which we have described above, dated back to the late 1940s when, after independence had been granted, their role in the political party was a source of embarrassment. Left without a solution then, this problem continued to color Masyumi's dynamics and contributed significantly to the 1952 split.

\section{Which Place for the Ulama? Structural Problems as}

\section{a Source of Malaise After the Golden Age of the Revolution}

Quite influential during the Dutch colonial period, the ulamaknown as kyai, syekh, ustadz, and other titles varying from region to region-gained prestige from official posting given to them by the colonial government. Under the Japanese occupation, they were the largest recipients of leadership posts within the Masyumi, ${ }^{19}$ which was created in November 1943. But, as has been underscored by Muhammad Asyari ${ }^{20}$, these religious leaders, often coming from rural areas, were ill-prepared for national functions and had great difficulties in defending their interests compared to nationalist leaders, who, ever since the Dutch colonial period, were quite well-versed in subtle political games. For this reason, at the time of the transformation of Masyumi into a political party in November 1945, they gladly left to others (like Sukiman, Abikusno Tjokrosujoso, or Wali al-Fatah, all of whom had headed Islamic parties before the war) the executive jobs, preferring for themselves the role of counseling and moral guidance.

Masyumi's structure was clearly a result of this role distribution between religious leaders and political cadres. Whereas these cadres, mostly from PSII and PII, received most of the directory board (Dewan Pimpinan) posts, the ulama, both from NU and the Muhammadiyah, were given the upper hand over the religious assembly (Majelis Syuro), whose mission was to guarantee the conformity of the executive's decisions with Islamic teachings. Thus, Kyai Hasyim Asy'ari, NU's rais aam, who himself showed little interest in politics, was seemingly happy to head the Majelis Syuro. His son, Wahid Hasyim, one of the traditionalist leaders most capable of entering into politics, received the Majelis Syuro's vice-presidency. Indeed, the Majelis had initially a major role within Masyumi as it was to be consulted by the leadership on religious questions and its advice was binding. 
During the revolution years, this balance of power within Masyumi performed relatively well: the ulama would give their religious blessing to the struggle against the former colonizer, and as such, were present and honored at the national and local meetings of the party. In January 1946, for example, al-Djibad, the Masyumi daily during the revolution years, reported a series of meetings between the Masyumi leaders, the ulama and the Muslim militia (Sabilillah and Hizbullah), ${ }^{21}$ aimed at "guaranteeing the establishment of a Darul Islam or Islamic state". ${ }^{22}$

The Majelis Syuro was also regularly asked for advice. Thus, in June of the same year, the Masyumi leadership took care to publish the Majelis Syuro decision allowing lenders to receive a supplement (tambahan) to the lent sum in the large national lending that it was advocating. ${ }^{23}$

Thus, in a situation indeed favorable to unity and religious exaltation, the holy war of the Indonesian people against its former colonizer appears to have been the golden age of cooperation between political cadres and ulama. Wahid Hasyim himself later emphasized the complementary nature of the two groups at that time: the first had strong general theoretical knowledge and clear political competence, while the second, the ulama, enjoyed great influence with the common people, but because they were badly organized nationally, such influence was limited to their own regions. ${ }^{2+}$

This touching unity has not escaped embellishment over the years-let us not forget that, already in the first months after the proclamation of independence, the traditionalists requested that the Ministry of Religions be held for a few months by the modernist H.M. Rasjidi. After the end of the revolution in 1949, the "complementary" nature of the two currents of Islam was no longer so evident. With the end of the war against the former colonizer, appeals to holy war were no longer necessary and could even become embarrassing. The rebellion started by Kartosuwirjo, who proclaimed an Islamic state in West Java, discredited earlier slogans in favor of an Islamic state, that the Masyumi itself had used some years back but which were now rather out of place as Masyumi became eager to participate officially in coalition governments. ${ }^{25}$

This development led to an increasing domination of the political wing within the party. It started with a change of the Majelis Syuro status at the Masyumi congress in 1949 in Yogyakarta. The Majelis became merely a consultative body without real influence on the 
political line of the party. The NU leaders protested against what they perceived as a breach of the initial agreement. Starting from then, "the problems were tackled exclusively from a political angle, without taking into account religious directives". ${ }^{26}$ In the midst of the crisis, criticism was now loose and old disagreements resurfaced.

The NU leadership blamed the Masyumi for having surpassed its political role in organizing social and religious activities, thus taking over prerogatives of party members. ${ }^{27}$ Soon after the Yogyakarta congress, the NU decided to create a Committee for Political Guidance, as a means to stem its loss of political influence within the Masyumi. ${ }^{28}$

In this emerging conflict, organizational problems were not the only grievance. The demeaning tone often used by modernist leaders toward religious dignitaries contributed significantly to the ulama's malaise. During the 1949 congress, Mohammad Saleh, mayor of Yogyakarta and member of Masyumi, had thus explained that politics was a domain too complex to be left in the hands of the ulama. The NU representatives protested, and, as the orator refused to withdraw his statement, thirty NU delegates left the room. Shortly afterwards, during a party meeting in Bogor, Wahid Hasyim's speech could not be heard over the jokes and chatters of the assembly. ${ }^{29}$ The mood worsened as it was precisely those within Masyumi who thought they could do without the ulama's counsel who were named to key executive posts in 1949. Mohammad Natsir became president of the party's counsel (Dewan Pimpinan Partai) and Sukiman was nominated president of the party, a title he kept until 1951 when he became president of the presidium, and then vice-president ranking below Moh. Natsir at the 1952 party congress.

This new generation of modernists came from the same educational background as the earlier generation, from the Dutch educational system. But, whereas Sukiman, who had little qualification in Islamic learning, had always shown the greatest respect toward the ulama, Natsir was much less respectful toward them, as he himself had acquired a solid religious training and thus did not feel the least inferior. Sukiman, a Javanese like most of the major NU ulama, had contributed to upholding a certain harmony within the party, between the political cadres and the ulama. ${ }^{30}$ Sukiman was present at the Palembang congress, but refused to intervene before the vote on the split from Masyumi was completed. ${ }^{31} \mathrm{He}$ clearly had the support of the traditionalists in the conflict that pitted him against Natsir in the control of Masyumi. Natsir himself came from West Sumatra 
and had had his religious training for the most part from the Persis ${ }^{32}$ major thinker, Ahmad Hassan, a convinced reformist and a stringent critic of traditionalist Islam. In his famous 1940 polemic against Soekarno in Pandji Islam, Natsir blamed Kemal Atatürk for not using his power to eradicate "spirits, polytheism and brotherhoods" (takbyul, politeisme dan tarekat) in order "to purify Islam". ${ }^{33}$

Significantly, the rise of Natsir in Masyumi coincided with the arrival of Kyai Wahab Hasbullah" ${ }^{3+}$ at the head of the Nahdlatul Ulama, after the death of Hasyim Asy'ari in 1947. Wahab was an ulama with strong interest in politics and had played the greatest part in the creation of the Nahdlatul Ulama in 1926. Thus, after the earlier complementary nature of Sukiman and Asy'ari came the time of tough competition between the two new leaders (Wahab and Natsir), both convinced that their own political and religious skills allowed them to do without the other.

It is no wonder that, given the evidence of their increasing loss of influence within the Masyumi and the worsening of the relationship with the new up-coming Masyumi generation, the ulama were tempted by the adventure of leaving the party altogether and creating their own. With the loss of the Ministry of Religions position in the Wilopo cabinet, they saw the disappearance of their last advantage in their long cooperation with the modernists. The step to withdraw was all the easier to make as the political context was now most suitable for it.

While one should avoid oversimplification, making the split the result of conflicting rivalries between religious dignitaries on one hand and political leaders on the other, it appears however clear that most of the NU representatives were sitting in the Majelis Syuro, that is, as religious scholars and not as political executive leaders. ${ }^{35}$ Other socioreligious organizations that were also members of the Masyumi, like the traditionalist al-Jamiyatul Wasliyah and the modernist Muhammadiyah, took greater care not to let themselves be confined to purely religious posting. ${ }^{36}$ Probably, the Nahdlatul Ulama thought that, as was the case within its own organization, a dominating role would be naturally granted to the Majelis Syuro within the Masyumi. But, far from being a pure coincidence, this sharing of responsibilities was rather the result of diverging perceptions of the State and its functions. This brings us to reflect further on the tangible political, social and religious divergences between the modernists and the traditionalists, as expressed in their respective programs. 


\section{Were there Two Irreconcilable Political Projects?}

The programs of the two political parties, the NU and Masyumi, were presented in 1954, the year preceding the first general elections. The two rival parties distinguished themselves first and foremost by their different sources of inspiration.

Recalling the principles adopted at the time of its creation, the Nahdlatul Ulama proclaimed it wanted to "firmly establish the sharî' $a$, according to one of the four schools of law, Hanâfî, Mâlikî, Shâfi' and Hanbâlî, and see to it that it is applied as positive law developing into a society, in the fields of religious practice, marriage, relations between humans, criminality and morals". ${ }^{37}$ The NU was thus recognizing the four schools of law as the unique source for its political program (although it mainly follows the Shafiite school of law) and thus confirmed the unacceptable nature of personal interpretation of the sacred texts (ijtihâd).

Masyumi was interested in not limiting its influence through restrictive statements, and avoided declarations of its precise religious dogma and theological aspirations in its political program. To its leaders, it seemed that following one or the other school of law was a "personal affair", ${ }^{38}$ yet in December 1954, the Majelis Syuro decided that the party respected all four Sunni schools. However, a look at the political writings of its main leaders ${ }^{39}$ shows clearly that it was the interpretation of texts (ijtihâd) that should guide the legislator, except for certain untouchable rules established by the Qur'ân and the Sunnah in specific fields, like cult practices (ibâdab). This basic difference between the traditionalist and the modernist movements was widely commented on by the NU, which underlined its own identity in these terms: ${ }^{40}$

Different from the NU party which clearly underlines the question of the four schools of law in its statutes, the Masyumi fails to do so. Many of its members, individually, are likely to be members of one or the other school, but the party makes no mention of this. As the Majelis Syuro at the Masyumi Surabaya congress made a statement that the party "respected" the muzhab, it means to us that the defense of these schools of law is not an essential goal of the party.

These divergences on sources aside (ijtibâd versus taqlîd), the political platforms of the two parties sound quite similar, but maybe because they remain rather vague: both parties favor a state of law, democracy-based on Islam, with the NU insisting more on its "national" character, ${ }^{+1}$ and Masyumi on its "republican" form. ${ }^{+2}$ In the 
two platforms, the term Islamic State was avoided in favor of more nuanced formula: "National State based on Islam" ${ }^{43}$ for the NU, and "State of law based on the principles of Islam" for Masyumi. ${ }^{44}$

The second article of both platforms proclaimed the principle of a guarantee of human rights and religious freedom. But, whereas Masyumi explicated that these guarantees held for both Indonesian citizens and foreigners, the NU only guaranteed "the freedom to practice a sound religion and the freedom to develop ideologies which would not have damaging effects". ${ }^{45}$ No explanation followed.

Both parties also agreed on the form of government: the cabinet should be presidential and responsible to the Parliament. A two-chamber assembly, the Parliament should include an assembly of people's representatives and a senate that would gather representatives of the regions. But for the Nahdlatul Ulama, the high chamber had to have competence in Islamic law, and would thus be the supreme arbiter. ${ }^{40}$ How to proceed to bring about this predominance was not explained. This was an idea close to that of some Masyumi leaders, but which did not appear in their program: the establishment of a Supreme Islamic Council in charge of seeing to the conformity of the laws with the untouchable principles of Islam. ${ }^{47}$ The two parties also favored a measure of autonomy for the regions, but kept clear of advocating a federal state proper.

In the explanations concerning its platform, the Nahdlatul Ulama insisted that the head of state had to be a Muslim. This condition also applied to the ministers "except for those who did not have direct responsibility in a spiritual field (public works, health or finances for example)". ${ }^{+8}$ The Masyumi platform did not mention such condition but, here again, some of its leaders ${ }^{49}$ mentioned in their writings the desire to see this condition, that the President - and only the President - be a Muslim written into the constitution.

Economic and social matters were unequally treated in the two platforms. The NU only declared that these questions would be settled according to the norms and the ways of a democracy. The Masyumi platform, of socialist inspiration, was offering much more detail. The Masyumi was in favor of a guided economic system. Moreover, it insisted on equality between men and women, whereas the NU remained silent on the subject. The last fundamental difference between the two Muslim parties was that Masyumi displayed a greater measure of anti-communism than NU, be it in its official documents ${ }^{50}$ or in the election campaign. The traditionalist party merely condemned 
the imported character of this ideology, and reminded the people that communism was advocating atheism, stressing that a believing communist was not considered a complete communist. ${ }^{51}$

All in all, the two parties did not differ significantly on institutions, apparently showing no major divergence that could have been the source of the split. It should be noted, however, that none of the two platforms settled clearly the question of the place of religious dignitaries in the State. One should think that this very question might have caused a continuing source of conflict in case of joint exercise of power, as both movements had been unable to settle this issue within Masyumi itself before the 1952 split, as we have seen above. Moreover, one can also presume that more differences would have appeared in the exercise of power, as Masyumi was far less precise on the fields in which Islamic law should be applied, and on the authority responsible for this delicate question.

In short, we can say that the Nahdlatul Ulama was basically more clear-cut in its "Islamic-minded" program, with unambiguous references to the mazhab, to the Islamic state, to the implementation of shari' $a$, to the council of ulama as ultimate arbiter, while asking more ministerial postings for Muslims. Masyumi sounded more liberal, asking for no postings to be specifically reserved for Muslims, but it was also more vague on religious law issues. On the whole, it seems that there was less soul-searching within the Nahdlatul Ulama than within the Masyumi, which had to accommodate a variety of modernist and reformist intellectuals with more or less radical views.

\section{The Impact of the Religious Row}

\section{at the Village Level: the Rituals}

Apart from the strictly political stakes that we have so far described, the row between traditionalists and reformists was one of religious dogmas which expressed themselves more or less acutely from region to region, from village to village. It is difficult to measure this impact, as today there is a strong will to down play hostilities that often expressed themselves in down-to-earth harassment.

By 1952, at the national level, the debate had abated compared to the pre-war period, as the leaders of both groups seemed to have reached a modus vivendi: they tried not to insist on subjects which had divided the Muslim community in the 1920s and the 1930s. This was particularly true of the thorny issue of the start of the fasting month. ${ }^{52}$ At the time of the general elections, the Masyumi leaders, 
eager to represent the whole Muslim community, took great care to adopt a tolerant attitude on these issues and never to criticize publicly NU leaders on this. The fact that traditionalist organizations like al-Jamiyatul Wasliyah, al-Ittihadiyah or Mathla'ul Anwar ${ }^{53}$ could stick to the Masyumi until the 1960 s is a vivid testimony to Masyumi's success at avoiding turning the conflict into one of religious dogma.

NU's attitude on dogma was more unbending, something natural as the new party had to underline its difference from the Masyumi if it wanted to win over Muslim voters. Thus, when in 1952 the NU adopted a resolution that Muslims should follow one of the four schools of law and that they should become members of those political parties following one of these four schools, ${ }^{5+}$ the traditionalists' departure from Masyumi had a distinct religious connotation.

While at the national level, the NU leaders remained mostly moderate in the expression of their religious conflicts with the reformists, ${ }^{55}$ at the local level, these controversies could translate into real disputes. H. Marcoesyah, ${ }^{56}$ a local Masyumi leader in Banjarsari (West Java) in the 1950 s, speaks of the sharp tensions between the two communities on questions of rituals. Whereas the political conflict remained very limited in his village, even after 1952, due to the fact that the parties' political platforms remained vague, the questions of dogmas and rituals were, on the contrary, tangible for villagers, especially as both competed for the control of the local mosque. The local dimension of the conflict was best analyzed by a young Indonesian scholar, Muhammad Asfar, ${ }^{57}$ who worked in the village of Tunjung Mekar (Lamongan regency, East Java) in the 1970s and 1980s. There NU traditionalists and Muhammadiyah reformists had to share the same mosque and conflicts were at times acute. The author listed nineteen points of disagreement, mostly concerning rites, between the two communities. The main points being: the number of azan calls to prayer (two for the NU, one for the Muhammadiyah), the raising of hands at the time of prayer (qunut) on Fridays (Muhammadiyah adherents leave them down), the pronunciation of niat before the prayer (practiced by the NU, rejected by the Muhammadiyah), ${ }^{58}$ the number of rakaat pronounced during the sholat Tarawih (eight for the Muhammadiyah, twenty for the NU), the number of sermons or kbotbah on friday (two for the NU, one for Muhammadiyah); some rituals are proscribed by the Muhammadiyah, like tablilan, or prayer for the dead, the sufi dhikir, and the visiting of saints' tombs (ziarah). 
Given these divergences of rites, the choice of the imams who will lead the five prayers at the mosque in Tunjung Mekar is most relevant. The sholat Maghrib being the prayer attended most, it is a key moment for the NU to introduce its dhikr. Another key prayer is the sholat Subuh, as the imam in charge will inevitably be the one to deliver the ensuing religious lesson. As such, he has the upper hand on the children's education, and in particular, on the choice of the Qur'ânic verses to be commented on..$^{59}$

Muhammad Asfar shows quite clearly in his study how the NU tried to resist the "newcomers", that is the reformists, who little by little managed to impose their ways, thanks to the support of some officials converted to reformism. Feelings of exasperation accompanied each organization in its tough battle to protect or fight for its convictions. ${ }^{60}$

These quarrels monopolized the energies of local leaders, each of them trying to seek the support of the administration official most likely to side with him. As noted by one Muhammadiyah activist, confrontation with the other Muslim group (saudara seiman, that is the traditionalists) required the adoption of real "strategies", and was thus viewed as more challenging than confrontation with the infidel (kafir), against whom [open] war was possible. ${ }^{61}$

These divisions have touched certain village communities for decades, as shown by the memories of one NU activist, former president of the Muslimat organization (the NU women organization), Madame Asmah Syahroni. ${ }^{62}$ Speaking of her youth in Timbuk Baru, Kalimantan, in the 1930s, she explained that the two communities distinguished themselves first by their clothing. The first women dressed with a veil tied under the chin were coming from West Sumatra and could speak Dutch.

They wore the kain and kebaya and a selendang (long shawl) they would pull around their head under the chin. They came from West Sumatra and could speak Dutch. For us, it was unimaginable, we were for non-cooperation. Like them, we wore the kain and kebaya, but our kerudung, open, let our neck open. Not all Muhammadiyah women wore this jilbab, others wore the kerudung like us since the age of 8 . But we would take it off at home, not them.

As for the reformist men, they wore a tie and a jacket to go to the mosque. In the village, on the contrary, traditionalist men wore the sarong (rectangular piece of fabric wrapped into a long skirt) and the kopiah (black head cap), a way to reject copying the Dutch colonizer. The prayer locations were distinct for the two groups: 
The mosques were distinct. My father, for example, did not work on Friday because he had to ride $9 \mathrm{~km}$ by bicycle to go to "his" mosque. The mosque that was situated $2 \mathrm{~km}$ away was not proper to him. Thus, he would lose one whole day to go to the other mosque.

Ritual issues would later decrease in importance because a modus vivendi was found and because some practices could find their ways into those of the other group..$^{63}$

\section{The Perpetuation of the Split}

\section{over Guided Democracy and the New Order}

Given this competition present at the local level, and given the rivalry within the structure of the Masyumi party over the ulamas' place, one may wonder why Masyumi reacted with such apathy to the decision of the Nahdlatul Ulama to create its own political party in 1952. This relative indifference may be due to the conviction, which was then widespread among modernist leaders, that the NU was not really capable of establishing its own political project, ${ }^{64}$ and that the three parties which had just left them would be equally unable to unite their efforts. On this last point, their analysis proved true. The new Muslim League, which the three parties joined after 1952, never became a serious alternative to Masyumi. The League remained at an embryonic stage, and it never turned into a real election alliance.

The 1955 general elections, which proved NU's success as a political force, were a surprise and proof of the Masyumi leaders' mistake in evaluating NU's strength. The voices of the Islamic community were almost equally distributed into the two parties (Masyumi $20.9 \%$, NU $18.4 \%$ ). The Masyumi election strategists had largely underestimated the ulamas' capacity to mobilize the electorate in their traditional strongholds, East and Central Java, so that they had almost exclusively directed their campaign against the PKI's communists and to a lesser extent against the PNI's nationalists. Nothing or almost nothing had been done to try and win back the traditionalist voters. When the media touched the issue of the NU during the campaign, it was to express its satisfaction at the cooperation between traditionalists and modernists within the Burhanuddin Harahap cabinet. These electoral tactics, which centered on the distinction between Islamic and non-Islamic parties, seemed to comfort the electorate in the idea that to vote for one or the other Islamic party would finally make not much difference.

On the contrary, the NU was accusing Masyumi of not being 
"mazhab-based", that is of not recognizing the authority of the four schools of law. It also emphasized NU's links to Java's cultural heritage (wayang and ketoprak), the charisma of local kyais, and gave a place to female politicians, following the example of other political parties. Both parties accused each other of having cooperated with the Dutch: Masyumi spoke of NU's following the "mazhab of Charles van der Plas", a Dutch official supposed to have pushed for NU's creation in 1926, while the NU responded that the way the modernists were dressed, following the western ways, proved rather it was Maysumi which was closest to the Dutch. ${ }^{65}$ Allegations of corruption against NU leaders were also made, which were never proven..$^{66}$

With the 1955 election confirming the emergence of a strong traditionalist movement, the conditions for a new political balance had emerged that largely contributed to the perpetuation of the 1952 split. The new cabinet of Ali Sastroamidjojo, created after the proclamation of the official election results in March 1956, included five ministers from the NU, that is as many as Masyumi. Then came the time when NU increasingly supported Guided Democracy, whereas Masyumi fought it with great energy, leading to a deterioration of relations between the two major Islamic parties. Starting from 1961, when it agreed to take part in the Nasakom with the PKI as a means, it said, to counter PKI's influence from within the cabinet, the NU became the target of even more stringent criticism from the modernists. At the same time, several Masyumi leaders, including its chairman Moh. Natsir, were drawn into the PRRI rebellion, which pitched part of the West-Sumatra elites against Jakarta. ${ }^{67}$ The rebellion was motivated by a rejection of the centralized Jakarta economic as well as political policies and of the growing leftist sympathies of the new regime, all this in the context of the cold war. While condemning both the rebels and the government, Masyumi stopped short of excluding the rebel leaders from the party, a gesture of clemency that annoyed the Nahdlatul Ulama, a largely Java-based political party that had little sympathy for the regional rebellions. Just as was the case for the Darul Islam rebellion of Kartosuwiryo which started in 1949 in West Java, where the NU had to prove it was a party loyal to the Republic, to Soekarno but "not to Kartosuwiryo", the NU again was sticking close to Soekarno in the late fifties, partly because it had to prove more than any other political party, that it was not an "extreme-rightist" party, despite repeated accusations to the contrary. ${ }^{68}$

Thus, apart from a real but short cooperation within the Con- 
stituent Assembly, where both parties voted in favor of an Islamic state in 1959, where they did not reach the two-third majority requested, the first signs of political solidarity between the two Muslim parties were soon to disappear. In August 1960, a presidential decree issued by Soekarno forced Masyumi leaders to dissolve their organization, under the threat of a ban. In the course of this political crisis, neither the NU, nor the PSII, nor the Perti brought their support to the Masyumi cause. Only several NU figures intervened in a personal capacity: thus, K.H.M. Dachlan, second vice-rais aam, and Imron Rosjadi, ${ }^{69}$ head of the NU youth organization, Pemuda Ansor, joined members of Masyumi and of the Partai Sosialis Indonesia, also banned by Soekarno, to create the Democratic League on March 24 th, 1960. It was banned a year later. ${ }^{70}$

The rise in 1965-1966 of New Order, which condemned the Soekarno regime's drift, raised high hopes among the leaders of the banned Masyumi. Deprived of their organization, most of them thrown into jail, they hoped to get, in the name of their martyrdom, a place of first rank in the newly emerging political landscape. These expectations did not materialize, as the strategy of the new regime toward political parties in general was guided by its profound suspicion of their potential "to divide the nation". The New Order was more or less going further along the Guided Democracy line.

As early as May 1966, a group of old Masyumi and GPII ${ }^{1}$ leaders, led by Faqih Usman, tried to convince senior officers of the necessity to rehabilitate Masyumi. But it soon appeared that this project was meeting a strong opposition. On January 26th, 1967, General Suharto announced that the armed forces and the soldiers' families who had suffered from the campaigns against the Darul Islam and then against the PRRI, were not ready for a rehabilitation of the Masyumi. ${ }^{72}$ Facing this impasse, the Muslim leaders agreed, with much regret, to establish a new political party, the Partai Muslimin Indonesia (Parmusi). This party was authorized in January 1968 by the new regime, under the strict condition that no former leader of Masyumi be included in the party leadership. This prerequisite, which Suharto had promised to revoke after the general elections, ${ }^{73}$ was reiterated when the Parmusi met at its first congress in Malang in December 1968. Complying with a request from Suharto, the Parmusi had to give up the newly elected party leadership to install other activists closer to the government. ${ }^{7+}$ An attempt by Moh. Hatta to promote the emergence of a modernist political Islamic movement through 
the creation of a Partai Demokrasi Islam met the same rebuff from the government. ${ }^{75}$

These episodes showed clearly that the regime was in no mood to accept the return to politics of those who, in 1957-1958, had proved to be the most fervent advocates of a western-type parliamentary democracy, that would give some (undefined) space to Islamic law. The New Order of General Suharto, which was now reorganizing the political landscape through a sophisticated arrangement of functional groups, could not acquiesce to the reemergence of a political movement that had opposed similar attempts several years earlier. Moreover, through its pro-west modernism and its democratic culture, and above all its staunch anti-communism, the Masyumi could appear, in the eyes of the New Order generals, as a dangerous rival in the search for an American blessing..$^{76}$

The Nahdlatul Ulama leadership also had much to fear from the rebirth of the Masyumi. Apart from a likely loss of its now leading position over political Islam, the NU could also fear the possible loss of the Ministry of Religions to the modernists. There were already intensive attacks for its support of the Old Order. Indeed, Masyumi had fought the PKI differently, at an earlier stage and in a more open way than the NU. Under the leadership of Kyai Wahab Hasbullah, the NU had preferred to adopt an anti-PKI strategy from within the cabinet and within the Parliament-which had proven a success for example in the case of the Land Reform bill-which it believed to be more efficient, and in this way had taken the risk of apparent unconditional support of Soekarno. At the same time, the NU was the author of a robust resistance campaign against $\mathrm{PKI}$ actions ${ }^{7}$ in rural areas, a struggle which culminated in the 1966-1967 massacres in which NU's youth movement, Ansor, played a major role.

Thus, at the beginning of the New Order, a mood of mutual suspicion overshadowed the relationship between traditionalists and modernists, a distrust nurtured by the gravest rumors. For example, one of the figures advocating the rehabilitation of Masyumi, Husni Thamrin, accused Idham Chalid and Subchan ZE, two NU leaders, of having approached Ali Murtopo and other New Order figures to press the government to reject the election of old Masyumi leaders at the Malang congress. ${ }^{78}$

Moreover, the numerous efforts of the modernists to unite the different Islamic movements met with little sympathy within NU circles. In 1966, a call for a major Islamic gathering (Apel Akbar 
Ummat Islam) failed to materialize shortly after the "30th of September" movement. Again, in 1968, the idea was launched of a large Islamic assembly (Majlis Pimpinan Perdjuangan Ummat Islam or a Majdlis Permusjawaratan Islam), a project supported by general Nasution, but nothing came of it. ${ }^{79}$ The reformist Isa Anshary proposed then to revive the 1937-born MIAI, with some adjustments, but he had no success. The possibility of convening a new Islamic congress was mentioned. The last such congress dated back to 1949 , but its recommendations had been left largely unheeded..$^{80}$ The possible venue of such a congress raised debates with the NU: Djamaluddin Malik, ${ }^{81}$ a reputed film producer who became an NU activist, was rather positive as such a congress would "end all kinds of accusations against the ummat", and would prove the ummat's "loyalty to Pancasila and to the Indonesian nation's unity." ${ }^{82}$ But K.A. Achsin, a Bandung NU activist, thought on the contrary that "history had proven that union as it happened within Masyumi had been a failure, whereas the decision to quit Masyumi in 1952 had proven beneficial to the NU, which had in turn been able to survive difficult times." Achsin noted that no modus vivendi had ever been found with the modernists. ${ }^{83}$ The NU executive chief, Idham Chalid, did call for the ummat's unity, but in vague and unconvincing terms. The congress in early 1969, where 550 participants were expected, was first delayed until May, and then abandoned altogether. ${ }^{84}$ From the point of view of the traditionalists, unity had always been synonymous with domination by the modernists, and the NU had no intention of entering an alliance where it would again be in the position of the dominated.

\section{The Reformists' Slow re-Composition}

This failure of reformist Islam to reemerge as a legitimate political force became clear in the early 1970s and resulted in a split regarding what attitude to adopt toward the government. Some leaders chose to keep their distance from the PPP (Partai Persatuan Pembangunan), the sole Islamic party created in 1973 as a government-imposed merger of all Islamic parties. This was the case of the Muhammadiyah, although Muhammadiyah activists or sympathizers participated individually in the new political structure. The Nahdlatul Ulama, on the contrary, merged into the PPP and tried to dominate the new political party during the whole of the 1970 s.

Drawing on a very negative record of the Islamic situation in In- 
donesia, ${ }^{85}$ the old Masyumi generation, which was being pushed out of the political scene, soon retreated into preaching (dakwah), the only field where its activities were now tolerated. Thus, in 1967, they created the Indonesian Council for Islamic Predication (Dewan Dakwah Islam Indonesia or DDII), which remains even today, the refuge of Masyumi's hard-core activists. This expulsion from the political sphere was accompanied by an economic marginalization of Muslim middle-class entrepreneurs, numerous within Masyumi, who suffered from the economic policies of the New Order. A radicalization of the reformist Muslims' positions followed, which coincided with an increased influence of Middle Eastern Muslim ideas in the aftermath of the Arab-Israeli war. ${ }^{86}$

Replacing its tolerance toward Indonesia's Christians in the $1950 \mathrm{~s},{ }^{87}$ the old Masyumi leadership has spoken loudly against Christian inroads from the start of the New Order. The NU, as the holder of the Ministry of Religions, made, on the contrary, visible efforts to temper its own fear of Christianity. The DDII's anti-Christian, anti-Chinese and anti-Jewish discourse, which has sharpened over the years, is partly explainable by the bitterness resulting from their being frozen out of politics, but it has also been fed by post- 1965 conversions to Christianity in Java. Following the introduction of compulsory religious education in 1966, as a counter to communism, Islam and Christianity became sharper competitors, especially so in Java where part of the superficially Islamized population groups opted for Christianity, besides Hinduism. ${ }^{88}$

As for Moh. Natsir himself, his change was also a change induced by'different functions. From a political leader with a nationwide audience and prominence in the press, he became the patron of a wellorganized but isolated preaching group (DDII). This was no longer a time for bringing Islam to the mainstream center, but a time of competition with other religions at the local level.

On top of these manifold frustrations, the socialist-minded exMasyumi disapproved of the turn taken in economic development, which they noted included rampant corruption and a disproportionate economic role played by the Ethnic Chinese, to the advantage of a few in the top bureaucratic leadership. Although this criticism of corruption, of social inequalities, and later of nepotism was not exclusive to the ex-Masyumi-it was a general complaint among dissidents and politicians-the marginal reformists could later praise themselves, because of their forced non-participation in the New Order, 
for being free of any responsibility.

Thus, this Masyumi generation has kept a distinct commitment to the ideals of a western-type parliamentary democracy all along, indeed the only way that could lead to a return of their political role. This pushed them often in an antagonistic position, more or less open, with the New Order regime. Several of its leaders, first and foremost among them Moh. Natsir, undersigned the "Petition of 50" in the 1980s.

But the 1970s also saw the emergence of a new generation of Muslim modernists who were intent on drawing lessons from the past, a past seen as proving the failure of aliran-politics as divisive and unproductive. ${ }^{89}$ Nurcholish Madjid, chairman of the modernist Muslim Students Association (Himpunan Mahasiswa Islam Indonesia) became the spokesman of this group of intellectuals. Drawing a clear picture of Masyumi's failure in the 1950s, he called for an end to the political struggle in favor of a cultural approach aimed at a revitalization of Islam. This approach, best known through his formula "Islam yes, Partai Islam, no!", amounted to a staunch criticism of his elders within Masyumi, who had made the "mistake" of "sacralizing" secular institutions like political parties and organs of the state. This criticism was painful to the Masyumi leaders who had, for a time, seen Nurcholish as their main inheritor. Amien Rais, the up-and-coming figure of political Islam, then a prominent Muhammadiyah activist, was now moving closer to Moh. Natsir. While Nurcholish Madjid was speaking of tolerance and pluralism, Moh. Natsir was increasingly preoccupied by conversions to Christianity.

The 1970s also saw the rapid development of what was then called the Salman movement on Indonesian campuses. Stemming from the Salman mosque at the Bandung Institute of Technology (ITB), and influenced by their leader, Imaduddin Abdulrahim, these student groups recognized themselves as neither traditionalist nor modernist, and succeeded in Islamizing the secular universities through open discussions, mutual assistance, and the encouragement of strict adherence to Muslim devotional acts, including the daily prayers, the fast, and payment of alms (zakat) to the poor. ${ }^{90}$ This social work on campuses stood increasingly in contrast with the ulama's vain politicking in Jakarta.

The modernists thus experienced a significant split between "cultural" and "political" Islam in the 1970s, with the start of a reflection on Islam and its possible contribution to the well-being of society, no 
longer through a top-down approach but through a return to the economic and social spheres. A similar soul-searching became increasingly apparent among the traditionalists in the 1980s, leading to new dialogues among Muslim "neomodernists" or "renewalists" on both sides, although differences in theological thinking remained.

In 1984, the NU abandoned the PPP in a return to its initial nonpolitical goals (khittah 1926), and gave in to the government demand to adopt the national Pancasila ideology as its sole principle. The Muhammadiyah followed NU's example one year later convinced that there would be more benefit than disadvantage from the policy. While distributing its support to all political parties, including the government-supported Golkar, the NU thus finally gave the Suharto regime the legitimacy long sought for- thus following Muhammadiyah's ways. The acceptance of Pancasila as the sole principle by both organizations seemed even to close the case of the Islamic state.

This attitude of compromise, far from being a limitation, bore its fruits. It allowed both organizations to encourage and then take advantage of the conspicuous Islamization process that has been occurring since the 1980 s, both in civil society as well as in the state structure. ${ }^{91}$ At the same time, efforts to bring the Muhammadiyah and the Nahdlatul Ulama closer materialized in the meeting of their two leaders, A.R. Fachruddin and Kyai Achmad Siddiq, two moderate figures of great charisma. This new entente cordiale brought no conclusion, neither side having the will to create a common organization, but both were satisfied with their honeymoon with the bureaucracy. The 1980 s thus saw a rapprochement of the two major Islamic organizations now united in a so-called "cultural" approach, while political Islam was marginalized. It thus appears evident that the two Islamic movements were thus closest to each other in a time of "bijrah" from politics, when feelings of rivalry were absent.

Dividing lines remained within each movement. On issues of religious tolerance, for example, none showed a monolithic stance. Thus, a letter to John Paul II, published in a book titled Abuse of Diakonia to be Suspended (Diakonia is explained as social service through financial means), was co-signed by Moh. Natsir and the key NU figure Kyai H. Masykur, who was however an advocate of NU's retreat from PPP, on the side of Abdurrahman Wahid. ${ }^{92}$ Another cleavage concerns the implementation of the shari'a, which, according to Abdurrahman Wahid, is the key obstacle to any union. The "legal- 
formalistic" view demands its total implementation, whereas the "ethical" view stresses the non-formal character of an Islamic way of life, through morals and ethics. ${ }^{93}$ In other words, there is no consensus on how far the Islamization of the law should go and how far the Arabization of Indonesians' way of life should reach.

The 1990s saw the creation of the Association of Indonesian Muslim Intellectuals (ICMI) under the leadership of B.J. Habibie, in an apparent turnabout of the government's earlier concern that promotion of religious identity would endanger the country's unity. For Suharto, it was the final touch to a new strategy of instrumentalizing political Islam at a time when the armed forces were showing signs of weariness with his rule. ICMI was meant to embrace all Muslim groups, but the government's attempt to include Abdurrahman Wahid failed. The NU leader chose to avoid ICMI, condemning its bureaucratic vision of Islam and the new sectarianism that inevitably would go with it.

In doing so, he not only deprived the new Muslim group of full legitimacy, which would have made ICMI the only pan-Indonesian Muslim organization, but he also deprived Suharto of total Islamic support.

But the door for the rise of political Islam was now open, in the sense that the communitarian discourse was re-legitimated. Whereas in the 1980s, journalists would count the number of military and nonmilitary ministers, in the 1990 s, the media counted the number of Muslim and non-Muslims ministers. ICMI introduced what was called "proportionality" politics, a development criticized by some Muslim intellectuals who saw this as a dangerous turn for the nation's unity and who argued in favor of "meritocracy".

In the early 1990s, the Muhammadiyah leadership changed hands, from the low profile and respected religious scholar Ahmad Azhar Basyir to the high profile politician Amien Rais. A change of leadership did not take place within the Nahdlatul Ulama despite repeated vindictive efforts to oust Wahid, by both political Islam (which included both reformists and traditionalists) and the government in 1992 and in 1994.

The cultural and political Islam rift between the two new leaders of NU and Muhammadiyah grew as two different visions of Islam's possible contribution to the well being of Indonesians emerged. Amien Rais strongly believed in an Islamic solution to the evils of modern society, with a strong rejection of the Western model. Wahid saw 
this as a mystification of an "Islamic" solution, a dangerous utopia for the unity of the archipelago. The NU chief urged for a reflection first on the kind of society wanted by Indonesians.

In the course of the 1990s, Wahid thus continued his efforts to "modernize" the NU, now countering the government's strategic reversal. He was more and more alone in trying to bring Islam to the "old" center, freeing it of any sectarianism, thus continuing the work of NU's rais aam Kyai Achmad Siddiq.

Amien Rais was more in tune with government policies of reIslamization, while at the same time being increasingly vocal about Suharto's failures. His prominence at the head of the Muhammadiyah being an effective shield against the government's heavy-handed handling of opposition, Rais survived practically untouched while other unknown dissidents were jailed (or murdered).

In a reversal of intellectual currents, the NU was becoming more open than those who presented themselves as the inheritors of Masyumi. This reversal is best illustrated by the way ICMI's main activists have persistently demanded a larger number of ministerial postings according to the proportion of the Muslim population in Indonesia, just like the NU had asked in 1955 that ministries carrying a spiritual charge be reserved to Muslims. Masyumi had made no such demand in 1955, like Wahid in the 1990s. This leads us to the question of whether Abdurrahman Wahid and Amien Rais (as chief of the Muhammadiyah until recently) are the spiritual sons of their respective movements.

Let us look at Wahid first. Despite NU's insistence on an Islamic state in the 1950s, and, on the practical side, on a specific attribution of ministerial postings to Muslims, the NU has been characterized all along the history of the republic by a major effort to be accepted as part of the "mainstream". Wahid Hasyim and other NU figures in the fifties gave higher priority to the country's unity than to their Islamic demands. Adherence to nationalism rather than to panIslamism was in line with NU's generally greater tolerance of local tradition and adat. On this, Abdurrahman Wahid perpetuates the NU line of working for national unity, tolerant of local religious practices, and of trying to drop the kolot (old-fashioned) image, in a constant effort to gain acceptance.

There is no such continuity for the reformists partly because they experienced greater discontinuity through upheavals in their approach to power. In the fifties, Masyumi was in power four times, holding 
the office of the Prime Minister in 1948-49, 1950-51, 1951-52 and 195556. By 1960, it was excluded from parliamentary life altogether. This long period of marginalization expressed itself in a radicalization that softened only after 1990 . The situation changed again in 1996, when Amien Rais abandoned the caution necessary for access to Suharto. $\mathrm{He}$, with other intellectuals, took the lead against the Suharto regime. His discourse as a figure seeking nationwide support became closer again to that of the Masyumi in the fifties, that is nonsectarian.

The continuity lies in Rais' view of Islam as a political ideology in search of a dominant place in the modern state, while the continuity in Wahid lies in its defensive effort to be accepted as part of the "mainstream". Probably, the area where both Wahid and Rais reversed attitudes most compared to their predecessors is in their position toward the West. Masyumi felt somewhat attracted by "Western" liberal ideas, whereas today some reformists (Amien Rais in a way, DDI in a stricter way, and KISDI much more definitely so) are known for their criticism of Western "decadence", ${ }^{9+}$ and their apparent acceptance of "conspiracy" theories which assert Western ambitions "to destroy Islam". Abdurrahman Wahid, on the contrary, represents an atypical traditionalist current-a line of thought also found among many moderate Modernist Muslim intellectuals-which urges a cautious and sober criticism of both the West and the Middle-East, filtering modernity, "taking what is good" and leaving what is bad. This is a reversal from the ulama's stance within NU, who showed a strong aversion to the "corrupting" influence of the West since the early 20 th century.

These changes are partly due to basic differences in attitudes towards the outside world in NU and in reformist circles. The reformists being more internationally-minded, their position is often influenced by developments abroad: whereas the cold war brought them closer to the United States in the 1950 s, today, America's foreign policy of socalled "double standards" brings them closer to the Middle-East.

Finally, at the end of the 1990s, Abdurrahman Wahid's constant favoring of "civic nationalism" and the "center", has started to sound dépassé in the tempest of the years leading to the ouster of President Suharto. The ex-president had been playing two cards at the same time: the-always-loyal-traditionalists and, more discreetly so, the card of the new radical Islamists gathered in the Indonesian Committee for World Islam Solidarity (KISDI). But some NU activists seemed to believe, from the end of 1996, that Suharto was trying to move away from ICMI, which the president now saw as a potentially serious competi- 
tor, no longer as a partner.

Wahid's gesture of support to Suharto during the 1997 electionshabitual and profitable since 1984-stood out because his parallel support of PDI as in earlier elections was now impossible after Megawati Soekarnoputri's ouster. In fact, his support to Soeharto's daughter Tutut was very much a rejection of the reformists in PPP, a second "pengembosan" (deflation), both for ideological and political reasons. The following events leading to Suharto's ouster have to be seen in the context of this triangular relationship between the government, the traditionalists and the reformists. Early 1998, NU's only option was to keep increasingly out of a power game that was not his, but evidently that of the best-placed protagonists: ICMI's core (who mostly favored B.J. Habibie as a first step) and Suharto.

\section{Conclusions}

This brief look at fifty years of the political history of Indonesian Islam brings us to the conclusion that the 1952 split was indeed a historical moment, but only as much as it was an event that illustrates the basic tendency toward division within the Muslim community. Among the ummat's leaders-the conflict's instigators-the split between traditionalists and reformists originated first in their different political cultures.

In contrast to Islamic Reformism, the traditionalists didn't intend to defend themselves and their beliefs through a single well-organized movement in the 1910s. As long as the traditionalist ulama controlled the majority of religious functions, were recognized in their social role, and felt no hostility from the government, they could adapt to any secular government. But because of the threat they felt to themselves as guardians of the religious and social order, they emerged as in independent organization in 1926, in a defensive reaction against "newcomers", who they felt were monopolizing the call of Islam for their own political aims.

The reformists' ambition was totally different. Their aim was to rule in the name of Islam in the modern state structure. Their ways and means atso differed. Converted to the values of Western liberalism, the reformists saw that their struggle could be achieved only in the framework of parliamentary democracy.

Because of their education (Western for many) -and because of their belief in the ijtihâd principle, which is better adapted to parliamentary life than the demanding figh books-the reformists were much more 
adept at the parliamentary game than the traditionalists. They were soon to dominate Masyumi, in which they had associated themselves with the traditionalists during the fervor of the Revolution. But the reformists made a fatal error. They underestimated NU's established strength in Javanese rural areas and were overwhelmed by a "majority mentality" syndrome, to use (in reverse) Wertheim's formula.

Convinced that the traditionalist ulama would be unable to build an autonomous and strong political movement by themselves, they pushed them aside into a purely decorative role. The NU leaders then had no choice but to create their own party if they wanted to survive.

We have seen the importance of the political context in the 1952 split, particularly of the early alliance between Soekarno and the traditionalists. However, we should not underestimate the divergences of political views of both Islamic parties, which were masked only by their meager and vague platforms.

For the Traditionalists, a state based on Islam should apply the essential parts of Qur'ânic teachings, while it would naturally be the job of the ulama to decide and apply Islamic law as it is already formulated, with answers to new questions being the ulama's prerogative. For the reformists, apart from some basic principles concerning religious practice and certain rules enunciated in the Qur'ân, it would be mostly up to the Parliament to decide how Islamic law should be applied. This was an easy way of opening to debate those unanswered questions on the interpretation of the law, and concerning this, the modernists had many diverging opinions. Thus, if the place of the ulama was not clearly defined, it was mostly due to the difficulty of finding one such place within the available set of institutions as well as the distrust felt toward the ulama as the sole authority on the law.

In this perspective, the 1952 split cannot be only attributed to a simple list of ritual differences and miscellaneous frustrations. Once both parties had admitted the impossibility of a lasting alliance, they could only try-given the fact that one could never reach a majority that would enable it to rule alone-to fight for the partner role that would give the regime the needed Islamic legitimacy, hoping then to have their cause progress through entrism.

It is this politics of "small steps", which was adopted first by the traditionalists under Guided Democracy, and then by ICMI's modernists under the new Order. For these periods and together with Wertheim, we can speak of a "majority with a minority mentality", based on the consciousness of historical divisions. 


\section{Endnotes}

1. We would like to thank Robert W. Hefner and James Siegel for comments on this paper.

2. Feith, Herbert, The Wilopo Cabinet, 1952-1953, a turning point in post-revolutionary Indonesia, Cornell University Press, Ithaca, 1958.

3. The term "modernist" has been used to describe the salafiyya-oriented movement in Indonesia since Deliar Noer's 1973 study of Indonesian Islamic movements from 1900-1940. This term however oversimplifies the Kaum Muda movement which is not monolithic. It fails to give the reformist dimension of the socalled Muslim "modernist" movement, through a return to the "purity" of Islam. Hence, hesitations among researchers about which term to use. While the term "reformist" stresses the question of dogma and rites, the term "modernist" stresses the willingness to use western-style instruments of modernity in education and social welfare. Because both trends were united in Masyumi, the use of one or the other term is possible, but fails to reflect the complexity of the Kaum muda movement. We have chosen to use the terms "modernist" or "reformist" depending on the emphasis put by certain figures, at certain times.

4. January 5th, 1973, the PPP was created as a merger of the four Muslim political parties, the NU, the Parmusi, the PSII and Perti.

5. Wertheim, W.F., "Indonesian Moslems under Sukarno and Suharto: Majority with Minority Mentality." in B.B. Hering Studies on Indonesian Islam. Townsville: occasional paper no 19, Centre for Southeast Asian Studies, James Cook University, 1989.

6. Created in November 1945 , the Masyumi party enlisted ordinary members, that is private persons, but also socio-religious organizations which, as extraordinary members, entrusted their political aspirations to the party. The two largest "extraordinary" members were the traditionalist Nahdlatul Ulama and the reformist/modernist Muhammadiyah.

7. Hikmah, May 10th, 1952.

8. The rais axm or rois axm is the title given to the highest post within the NU. He is the chairman of the Ulama's Council or Syuriah, who heads the organization, defines its broad guidelines and oversees the executive board or Tanfidziyah.

9. Then Masyumi's chairman.

10. These last two were NU members.

11. It was Moh. Rasjidi, in the second Sjahrir cabinet in 1946.

12. "soal insidentiel" in Indonesian.

13. Hikmah, April 16th, 1952.

14. "Riwajat singkat partai Nahdlatul-Ulama" in Kementerian Penerangan, Kepartaian dan Parlementaria Indonesia, Jakarta, 1954, p. 413.

15. Thus, the Kongres al-Islam refused the traditionalists' request to pass on to Ibn Saud their wish to see non-wahhabi rituals tolerated in Mekka. Early in January, a conference of the Modernists in Cianjur did not choose a single traditionalist to be part of the delegation invited to Mekka. The ulama then decided to create their own "komite Hijaz". To give it more weight, the NU was created. On NU's creation, see Noer 1980:243; Anam 1985:1-33; Bruinessen 1994:17-37.

16. The Madjelis Islam A'la Indonesia Council of Indonesian Ulama was created in 1938 and gathered most of Indonesia's Muslim organizations.

17. "Riwajat singkat partai Nahdlatul-Ulama" in Kementerian Penerangan, Kepartaitan 
dan Parlementaria Indonesia, Jakarta, 1954, p 412.

18. Feith, Herbert, The Decline of Constitutional Democracy in Indonesia, Ithaca, New York, Cornell University Press, 1962, p. 123.

19. The Masjumi or Madjlis Sjuro Muslimin Indonesia was created to serve the interests of the Japanese during the Second World War. When, in November 1945, Muslim leaders decided to create their own political party, they took advantage of the structure and of the name of this Muslim organization, but, of course, set themselves totally different goals.

20. The Rise of Masjumi Party in Indonesia and The Role of the Ulama in its early development. 1945-1952, MA Thesis, Mc Gill University, 1976.

21. Two Islamic militias linked to the Masyumi.

22. "Darul Islam atau Negara Islam" Al-Djihad, 28 January 1946.

23. Al-Djihad, 21 June 1946.

24. Asyari, op.cit., p 124.

25. A former Masyumi leader in West-Java, Kartosuwirjo led the Islamic guerrillas who, in January 1948, refused to retreat to Central Java, as demanded by the Renville agreement with the Dutch. His opposition to the Republic's leaders turned into an open rebellion when he proclaimed Indonesia an Islamic State in august 1949 .

26. "Riwajat singkat partai Nahdlatul-Ulama" in Kementerian Penerangan, Kepartaian din Parlementaria Indonesia, Jakarta, 1954, p 412.

27. K.H.A. Wahab Hasbullah, in his opening address to the Palembang NU congress in 1952, commented as follows after having explained that Masyumi organized celebrations of major Islamic ceremonies, gathered the Zakat and distributed it partly to the poor, activities which should be left to "member organizations" of Masyumi: "In view of the above we realize that the majority of our ummat have not understood the dividing line between the roles of a social-charitable organization and a political party. Therefore many of them are confused and sometimes appear suspicious." in Naim Mochtar, Indonesia's Nabdlatul Ulama Movement: factors that led to its emergence as a political party, New York, 1961, p 9.

28. Madjelis pimpinan politik: this committee was abandoned when the NU became a political party.

29. Noer, Deliar, Partai Islam di pentas nasional, Pustaka Utama Grafiti, Jakarta 1987, p 87.

30. Whereas Natsir did not hesitate to criticize publicly the haj policies of Wahid Hasyim, then Minister of Religions (Asyari, p.127).

31. Noer, Deliar, Op. Cit. p 225.

32. The Persis or Persatuan Islam was created in 1920. Contrary to the Muhammadiyah which gave priority to the spread of its ideas in a calm and tranquil way, the Persis seemed to enjoy debates and polemics. It is said that it liked "to defy people who disapproved of its opinions and its ideas, inviting them to debate" (Noer 1980:103).

33. Noer, Deliar, Gerakan Moderen Islam di Indonesia 1900-1942, LP3ES, Jakarta, 1980 , p. 313.

34. Wahab was a man of convictions and a man of action. When he finally set up the Nahdlatul Ulama in 1926, he declared that, "after ten years of defending the ulama accused and criticized from all sides", he was ready to go back to his 
pesantren to devote himself totally to education if he could do nothing to change the situation (Haidar 1995:95).

35. In 1945, three of NU representatives were in the Madjelis Sjuro, and only one was in the executive board. After the 1951 congress, the NU held only two out of 21 seats in executive positions.

36. Thus, H. Abdurrahman Sjihab, an ulama from the al-Jamiyatul Wasliyah, member of the Majelis Syuro, also took a leading role in the Masyumi party from 1949 to 1950 . Kasman Singodemedjo, member of the Muhammadiyah, held a seat in the Majelis Syuro since 1945 and then became party secretary general in 1949 (Noer op.cit. p 225).

37. "Partai NU meneggakkan sjariat Islam secara prinsipieel-konsekwen dengan berhaluan salah-satu daripada empat madzhab: Hanafy, Maliky, Sjafi'y, Hanbaly, serta memperjuangkan terlaksananya sebagai hukum-hidup jang berkembang dalam masyakarat meliputi lapangan2 Ibadat, Munakahat, Mu'amalat, Djinajat dan Achlak."

38. See the declarations of Isa Anshary, head of the West Java Masyumi branch (Abadi, February 2nd, 1954).

39. See, among others, Natsir, Moh. Islam sebagai Dasar Negara, Bandung, no date.

40. Pengurus Besar Partai Nahdlatul Ulama, Risalah Politik 5, November 1955, Jakarta, p 9.

41. Negara nasional.

42. Negara hukum berbentuk republik.

43. Yang berdasar Islam.

44. Negara hukum berdasarkan atas adjaran-adjaran Islam

45. "Kebebasan memeluk agama yang sehat dan kebebasan mempunyai serta mengembangkan pikiran dan paham jang tidak bersifat merugikan".

46. "... serta pula mencerminkan keahlian dalam lapangan hukum Islam, yang merupakan pertimbangan terachir". One should note that this proposal reflected the Nahdlatul Ulama's own internal organization where the Tanfidziyah was in charge of the executive, whereas the Syuriah, was a guardian of the righteous path taken, as the most respected ulama saw to the respect of Islamic law.

47. Ahmad, Z.A. Membentuk Negara Islam, Djakarta, Widjaya, 1956.

48. Pengurus Besar Partai Nahdlatul Ulama, Risalah Politik 5, november 1955, Jakarta, p 11.

49. See, in particular Ahmad, Z.A. Membentuk Negara Islam, Djakarta, Widjaya, 1956.

50. See in particular its Tafsir Asas, on its principles.

51. Pengurus Besar Partai Nahdlatul Ulama, Risalah Politik 5, November 1955, Jakarta.

52. Noer, Deliar, Op. Cit. p 428.

53. Ibid., p 347.

54. Federspiel, H., op. cit. p. 161; Asyari, op. cit. p. 130.

55. Noer, Deliar, Op. Cit. p 428.

56. Interview, September 1996.

57. Dimensi-Dimensi Konflik Muhammadiyah-NU, Thesis ilmu-ilmu sosial dan politik, Universitas Airlangga, June 1989.

58. On this so called "ushalli controversy", see Bowen 1997:157-181.

59. For example, the reformists are keen to use the surat "manusia tidak akan dapat 
kecuali apa yang mereka usahakan", and are opposed to prayers in favor of the dead (tablilan), contrary to the traditionalists.

60. Thus, through the sudden calling of a meeting which the NU ulama could not attend, the mosque's takmir could make concessions to the Muhammadiyah in NU's absence.

61. One Muhammadiyah activist, Bapak Yasin, was quoted as saying: "When we are facing an infidel, the battle is not too difficult but when we are in front of a coreligionist [NU member], then we have to adapt our strategy." In Indonesian: "Kalau menghadapi orang kafir, kita tidak terlalu kesulitan, dengan perangpun jadi, tetapi menghadapi 'saudara seiman' sendiri yang sulit. Untuk itu perlu dihadapi dengan strategi yang tersendiri." (p. 211-212)

62. Interview, October 9th, 1995.

63. During the New Order years, for example, ziarah was less castigated by the reformists, who more often visited tombs at the time of Idul Fitri, while traditionalists were more often shying away from saying they were asking intercession in their favor.

64. At the time of the split, the reformist Isa Anshary of Masyumi asked ironically Kyai Wahab whether he had enough cadres to create his own political party. Wahab answered straight to the point: "If I buy a new car, the salesman will not ask me whether I have my driving license, will he? This question is irrelevant, because, if I did not know how to drive, I would put an ad: "driver wanted". And I am very sure that I would have a queue of drivers waiting in front of my door" (Zuhri 1987:399).

65. Fealy, Greg, Ph.D. Thesis, "Ulama and Politics in Indonesia: A History of Nahdlatul Ulama 1952-1967, History Department, Monash University, 1998.

66. Fealy, Greg, 1998:11.

67. February 15th, 1958, the PRRI was proclaimed. Sjafruddin Prawiranegara was Prime Minister, Boerhanuddin Harahap Minister of Justice and Defense, and Natsir its spokesman.

68. Zuhri Saifuddin, Berangkat dari Pesantren, Gunung Agung, Jakarta. 1987: p. 428.

69. Together with Kyai Bishri Syansuri and Achmad Siddiq, they were opposed to NU's entry into the new parliament, partly nominated by the government (Masyuri 1983:58; Zuhri 1987:484).

70. Noer, Deliar, Op. Cit. p. 402.

71. The GPII or Gerakan Pemuda Islam Indonesia was a youth organization close to Masyumi. It was suspected of involvement in the failed murder attempt against Soekarno in 1957, and was banned in 1963.

72. Ward, K.E., The foundation of the Partai Muslimin Indonesia, Interim Report Series, Modern Indonesia Project, Cornell University, Ithaca, New York, 1970, p. 25.

73. Ward, K.E., Op. Cit., p. 57.

74. The leader who failed to receive government approval was Moh. Roem, a former Masyumi leader, very close to Natsir. Agus Sudono, Naro and Sanusi, considered by the congress as too close to the government, had been sidelined (Ward, K.E. op.cit. p. 52).

75. From the first weeks of the New Order, within the Gerakan Demokrasi Islam Indonesia, part of the modernist elite gathered around Moh. Hatta. In a bid to follow the Muslim-democratic Masyumi tradition, they created shortly after- 
wards the Partai Demokrasi Islam Indonesia but could not convince Natsir and Prawoto Mangkusasmito to join them. Early 1967, Suharto explained to Moh. Hatta that the Masyumi would not be rehabilitated but that another party would take up its aspirations, and thus, the new Partai Demokrasi Indonesia could not be allowed. Hatta accepted this decision, with regret (Noer, Deliar, Aku Bagian Ummat, Aku Bagian Bangsa, Otobiografi, Bandung, Mizan, 1996, pp. 566-604.)

76. Being a very anti-communist party, Masyumi was always considered favorably by the American administration. In 1957 and 1958, during the PRRI crisis, there was talk of CIA aid to the rebels.

77. Ward, K.E., op.cit. p. 62 note 21 . In fact, the NU itself was divided as to the attitude to adopt toward Soekarno, who continued to support the PKI. This division was reminiscent of the 1959 division on the participation in Guided Democracy. The new generation, gathered in Ansor had criticized the "opportunist" attitude of its traditionalist leaders. It was the most staunchly anti-communist NU leaders who played the leading role after September 1965.

78. Ward, K.E., Op. Cit., p. 62.

79. Dutu Masyarakat (DM), 17. 6. 1968; DM, 25. 6. 1968.

80. Muktamar Kongres Muslimin Indonesia, 20-25 december in Yogyakarta.

81. Abubakar describes with an admiration the man as being the equivalent of Warner Brothers in Hollywood, but says his weakness was that he never produced films of "religious propaganda" (Abubakar p. 251)

82. DM, 28. 12. 1968.

83. DM, 22.6. 1966.

84. DM, 8. 1. 1969.

85. Kasman Singodimedjo, a former Masyumi leader, explained the obstacle to the ummat's unity as being due to "the search for material gains through government posts." Moh. Natsir said the Indonesian Muslim community was now "divided, without a defined goal... without proper conviction", in Islam and Poli. tics, Islam and State in Indonesia, Mintareja, Siliwangi, Jakarta, p. 20.

86. On Masyumi's development into the DDII, and the rationale behind its radicalization, see Robert Hefner's insightful "Print Islam: Mass Media and Ideological Rivalries among Indonesian Muslims", in Indonesia, No. 64, October 1997.

87. The anti-Christian stance of part of the Modernists in the 1920s and 1930s may have been partly linked to anti-colonialism. After independence, it changed and Masyumi held a discourse of tolerance toward Christians. While in power, it found allies in the Protestant Parkindo and in the Catholic party, to the point that the traditionalist Perti, through Sirajuddin Abbas, explicitly expressed regret over these alliances in 1956 (Abadi, 20.1. 1956).

88. Robert Hefner writes in "Print Islam" (1997) that many of the converts came from "what had been communist strongholds in East and Central Java". According to information I gathered in East Java, the population suspected of communist links often turned to Islam, becoming cautiously practicing Muslims (taat) in Islamic strongholds like Bangil for example. Thus, conversions to one or the other religion may have depended on the immediate environment, and what was felt "safest" for them.

89. We would like to thank James Siegel especially for his comments on this part of the article. 
90. Hefner, R. W. "Islamization and Democratization in Indonesia", in Islam in an Era of Nation-States, eds. Robert Hefner and Patricia Horvatich, University of Hawaii Press, Honolulu, 1997: p.90.

91. One of the Muhammadiyah leaders who pushed this development declared to Hefner (1997) later: "Yes, we compromised in accepting Pancasila, and there were many people who disagreed. But at first we didn't really understand what the consequence of this would be. Before there was one party identified with Islam. But look at what has happened. After being de-politicized, suddenly Islam is no longer confined to any one party but promoted by all of them."

92. The booklet was published by Dewan Dakwah Islamiyah Indonesia, Jakarta, in 1989, with a bilingual version in English and Arabic.

93. Muhammadiyah dan NU, Reorientasi wawasan Keislaman, eds. Yunahar Ilyas, M. Masyhur Amin, M. Darul Lalito, LPPI UMY, Yogyakarta, 1993, p. 117.

94. See Hefner 1997 on this.

Rémy Madinier, from Lyon-2 University, is currently preparing a Ph.D. thesis on the reformist-oriented Masyumi in the 1950 s.

Andrée Feillard is a research scholar at the French National Scientific Research Institute (CNRS), and works in particular on traditionalist Islam. 